\title{
Youth Community Gardening Programming as Community Development: The Youth for EcoAction Program in Winnipeg, Canada
}

\author{
Stephanie Fulford \& Shirley Thompson
}

University of Manitoba

\begin{abstract}
The Youth for EcoAction (YEA) program is a project of the Boys and Girls Clubs of Winnipeg involving at-risk youth. This community development program focuses on urban agriculture and community gardening and was developed using the Circle of Courage pedagogy. The program was analyzed through participatory methods. YEA youth interns built skills, improved self-esteem, increased environmental awareness, enhanced food security, and fostered their own social networks to help counter the attraction to gangs and dealing with other issues. Benefits were also felt at a broader community level, through positive environmental, social, and physical changes. Youth-serving agencies, community development organizations, and government policy makers could look to the YEA as a model for youth empowerment and community revitalization.
\end{abstract}

\section{RÉSUMÉ}

Le programme Youth for EcoAction (YEA) pour les jeunes à risque est l'œuvre des Clubs garçons et filles de Winnipeg. II met l'accent sur l'agriculture urbaine et le jardinage communautaire. Les Clubs ont développé YEA en recourant à la pédagogie du Cercle du courage. Pour analyser ce programme, les auteurs de cet article ont employé une méthode participative. Pour les jeunes, les bénéfices de YEA incluent le développement de compétences, une sécurité alimentaire accrue et la formation de réseaux qui les aident à échapper à la tentation des gangs et autres problèmes. À un niveau communautaire, les bénéfices comprennent des améliorations environnementales, sociales et physiques. Pour les agences jeunesse, les organismes de développement communautaire et les stratèges gouvernementaux, le programme YEA peut servir de modèle d'autonomisation des jeunes et de revitalisation de la communauté.

KEYWORDS I MOTS CLÉS At-risk youth; Youth gardening programs; Youth employment; Youth empowerment; Community development / Jeunesse à risque; Programme de jardinage pour jeunes; Emplois pour les jeunes; Autonomisation des jeunes; Développement communautaire 


\section{Fulford \& Thompson (2013)}

\section{INTRODUCTION}

Can a community garden provide more than just vegetables? The Youth for EcoAction (YEA) program, an afterschool gardening program, endeavours to grow not just food but also cultivate youth and communities through its work. This article analyzes the YEA program for its role in community development, considering the impacts on the participants and the broader community. The YEA program is an example of a "participatory, bottom-up approach to development" (Markey, Pierce, Vodden \& Roseland, 2005, p. 2) with an emphasis on the capacity building of at-risk youth and community enhancement focused on community gardens in low-income communities.

Community youth development

Community youth development emphasizes youth participation in contributing to one's community. For the purpose of this research, community development is defined, as per Douglas (1994), as "communities addressing problems and opportunities, on their own behalf, which they perceive to be of importance to their quality of life or their community's viability" (p. 10). Self-sufficiency, decision-making, and ownership (Loxley, 1986) are key to community development and, in the context of youth activities, point to the need for opportunities to build skills and relationships. Douglas (1994) raises questions that take into consideration the role youth play in community development, asking: what is being developed and by whom, and how is it being developed and on whose behalf?

Although many youth programs see marginalized adolescents as a problem, youth become the problem solvers in youth community development programs (Trinidad, 2009). Most conventional youth programs, according to Trinidad (2009), aim for social integration, which focuses on changing individual skills and competencies as program outcomes. In contrast, youth community development programs provide opportunities through youth participation to shift power dynamics, and they encourage youth to take an active role in community building and social contribution. As a result, youth community development programs achieve many additional positive outcomes at the family, neighbourhood, and community levels (Sutton, 2007).

Strategies for developing program capacity to foster youth participation in community change are based on asset building. Making communities better places for youth to grow up in is the goal of these youth programs. In a national study of youth programs, community youth development provided three major processes of participation: 1) social integration, 2) community involvement, and 3) civic activism (Sutton, 2007). By providing a space for youth to actively participate and contribute, youth and communities gain knowledge, engage in dialogue, and are able to reflect on how to utilize local resources to promote health and wellness and to prevent violence. Particularly effective to community change is incorporating a youth-led component to consider structural discrimination and injustices (Trinidad, 2009).

Community development and youth gardening

Garden projects have been organized to counter a host of contemporary social problems (Robinson-O'Brien, Story \& Heim, 2009). By promoting outdoor physical activity, gardens support public health efforts to improve community well-being and combat the obesity epidemic. Garden projects are widely used as a source of employment and training for at-risk youth, to reconnect them with nature thereby yielding many individual and social benefits (Gatto, Ventura, Cook, Gyllenhammer \& Davis, 2012; Lautenschlager \& Smith 2007; Ober Allen, Alaimo, Elam \& Perry, 2008; Rahm, 2002; Trinidad, 2009). See Table 1 for a literature review of six articles pertaining to youth gardening and community development, highlighting the program interventions and the findings by different research methods.

ANSERJ To be notified about new ANSERJ articles, click subscribe / s'inscrire ici. 
Fulford \& Thompson (2013)

Table 1: A literature review for youth gardening and community development

\begin{tabular}{|c|c|c|c|}
\hline Author & Intervention & Method & Findings \\
\hline $\begin{array}{l}\text { Ober Allen et al } \\
(2008)\end{array}$ & $\begin{array}{l}\text { Urban neighbourhood } \\
\text { youth gardening } \\
\text { programs. }\end{array}$ & $\begin{array}{l}\text { Case study based on } 32 \\
\text { interviews of African- } \\
\text { American stakeholders in } \\
\text { Flint, Michigan. }\end{array}$ & $\begin{array}{l}\text { Promoted youth development, } \\
\text { access, and consumption of healthy } \\
\text { foods. }\end{array}$ \\
\hline Rahm (2002) & $\begin{array}{l}\text { Science-based inner-city } \\
\text { youth gardening } \\
\text { education program. }\end{array}$ & $\begin{array}{l}\text { Observation and semi- } \\
\text { structured interviews. }\end{array}$ & $\begin{array}{l}\text { Provided a rich science education } \\
\text { by creating a youth-led curriculum } \\
\text { and hands-on investigation. }\end{array}$ \\
\hline $\begin{array}{l}\text { Lautenschlager \& } \\
\text { Smith (2007) }\end{array}$ & $\begin{array}{l}\text { Inner-city youth gardening } \\
\text { and nutrition program. }\end{array}$ & $\begin{array}{l}\text { The case study included an } \\
\text { analysis of in-depth and } \\
\text { open-ended interviews. }\end{array}$ & $\begin{array}{l}\text { Taught youth a better } \\
\text { understanding of the food system } \\
\text { as well as the gardening process. } \\
\text { Participants could better } \\
\text { differentiate healthy versus } \\
\text { unhealthy foods compared to youth } \\
\text { who did not participate in the } \\
\text { community gardening program. }\end{array}$ \\
\hline $\begin{array}{l}\text { Gatto et al., } \\
(2012)\end{array}$ & $\begin{array}{l}\text { After-school garden- } \\
\text { based nutrition classes for } \\
\text { Latino youth (LA Sprouts). }\end{array}$ & $\begin{array}{l}\text { A quasi-experimental } \\
\text { intervention was assessed for } \\
\text { its influence on behaviour } \\
\text { associated } \\
\text { with dietary intake and } \\
\text { psychosocial factors. }\end{array}$ & $\begin{array}{l}\text { Improved attitudes and preferences } \\
\text { for fruits and vegetables among } \\
\text { Latino youth, which may lead to } \\
\text { improved nutritional habits and } \\
\text { dietary intake and reduced health } \\
\text { disparities. }\end{array}$ \\
\hline $\begin{array}{l}\text { Lawson \& } \\
\text { McNally (1995) }\end{array}$ & $\begin{array}{l}\text { Youth employment } \\
\text { landscape program. }\end{array}$ & $\begin{array}{l}\text { Evaluation using mixed } \\
\text { methods. }\end{array}$ & $\begin{array}{l}\text { Provided at-risk teens with income, } \\
\text { job-training, safe after-school } \\
\text { activity, and self-esteem. }\end{array}$ \\
\hline Trinidad (2009) & $\begin{array}{l}\text { Rural, community-based } \\
\text { youth program } \\
\text { incorporated youth } \\
\text { community development, } \\
\text { critical pedagogies, and } \\
\text { Hawaiian epistemology } \\
\text { into organic farm work } \\
\text { placements and school } \\
\text { garden education. }\end{array}$ & $\begin{array}{l}\text { Case study in rural Hawaii } \\
\text { included an analysis of in- } \\
\text { depth, open-ended interviews } \\
\text { on which a content analysis } \\
\text { was conducted utilizing } \\
\text { critical indigenous qualitative } \\
\text { research. }\end{array}$ & $\begin{array}{l}\text { Improved nutrition and prevented } \\
\text { negative behaviours such as } \\
\text { violence, were evident in this case } \\
\text { study. }\end{array}$ \\
\hline
\end{tabular}

Like other youth-focused leadership, recreational, and training programs, youth gardening programs have been found to provide multiple benefits such as improved self-esteem and academic performance, skills development, and increased employability (Hoffman, Knight, \& Wallach, 2007; Robinson-O'Brien et al, 2009). Garden-based programs may improve vegetable and fruit consumption by youth by providing the opportunity to plant, harvest, and prepare diverse vegetables as well as berries and melons (Robinson-O'Brien et al., 2009; Story, Lytle, Birnbaum \& Perry, 2002). Also, training youth in gardening builds local capacity and livelihood assets, which helps to counter the attraction of gangs (Trinidad, 2009). Similarly, community-based recreation programs have reduced vandalism, lowered unemployment, improved social solidarity, and improved collective health and well-being (Briand, Sauvé \& Fréchette, 2011).

Inner-city youth gardening programs are being carried out in many large cities in North America, including Toronto, Vancouver, Chicago, Detroit, Los Angeles, and New York. These gardening programs offer urban youth growing up in an environment away from the natural world an opportunity to experience in situ biodiversity. Most of these programs are being run by youth organizations focused on at-risk youth (Lawson

ANSERJ To be notified about new ANSERJ articles, click subscribe / s'inscrire ici. 


\section{Fulford \& Thompson (2013)}

\& McNally, 1995). For instance, in Berkeley, California, the Berkeley Youth Alternative, a youth employment landscape program that includes a community garden patch, provides youth with "employment, a safe social scene, and a venue for rethinking their future" (Lawson \& McNally, 1995, p. 211).

Gardening programs also offer benefits to rural at-risk youth. For example, a program in a rural community on Oahu, Hawaii, that included a youth-led farm, school gardens, and training programs for youth, resulted in a local movement to develop a comprehensive plan and a sustainable local food system (Trinidad, 2009). The program was reported to have played a role in preventing a host of negative behaviours, such as violence, as well as in improving youth health, nutrition, and wellness (Trinidad, 2009).

Community gardens as a catalyst for change

A community garden is an allotment of land tended by a collection of individuals or by a group (Levkoe, 2006). Community gardens provide a source of fresh, safe, locally produced food, benefiting the gardeners themselves and the broader community, as gardeners often share their produce with friends, neighbours, and food relief programs (Fieldhouse \& Thompson, 2012; Patel, 1991; Thompson et al., 2011, 2012). Community gardeners decrease their food bill, and tend to have a healthier diet than their non-gardening counterparts due to increased consumption of fruits and vegetables (Twiss, Dickinson, Duma, Kleinman, Paulsen, \& Rilveria, 2003; Wakefield, Yeudell, Taron, Reynolds, \& Skinner, 2007). Gardening also provides an important reason for physical activity, a contributing factor to overall health (Twiss et al., 2003; Wakefield et al., 2007).

Community gardening has been shown to have a positive influence on mental health due to its social and relaxing nature (Levkoe, 2006; Wakefield et al., 2007). This benefit extends to the community as a whole by providing valuable green space. Green spaces benefit communities through the provision of communal gathering spaces and locations for children to play and explore, and by sustaining the local natural environment (Wakefield et al., 2007). Community gardens act as living, outdoor classrooms for gardeners, residents, and neighbourhood children. Community gardens provide a space to interact with nature, where children can learn the processes of the natural world first hand. Digging in the soil, examining bugs, and observing plants growing can be an important first step toward a better appreciation of nature (Wakefield et al., 2007). Experiencing and enjoying nature is considered a key factor in influencing individuals to adopt environmental stewardship behaviours (Chawla, 1998).

Community gardens also contribute to broader, long-term positive change. Community gardens can stimulate neighbourhood revitalization through the creation of beautiful, welcoming spaces (Brown and Carter, 2003). These spaces also act to build social networks through their use as community gathering spaces. In turn, improved social networks and connections play an important role in building community capacity (Wakefield et al., 2007).

Participation in community garden projects has been shown to act as a stepping stone for further involvement in food security issues and community development. By producing their own food, community garden members are reconnecting with the source of their food, which can stimulate critical thinking and action. Community gardens provide transformative learning in individuals and can stimulate involvement in further projects and/or activism related to food and community development (Levkoe, 2006). People have been inspired by the collective nature of community garden work, and by experiencing success and positive change through the gardens, they begin to engage in other activities toward building a stronger local community (Levkoe, 2006). 
Fulford \& Thompson (2013)

Figure 1: Timeline of Youth EcoAction in Winnipeg from 2004 to 2012

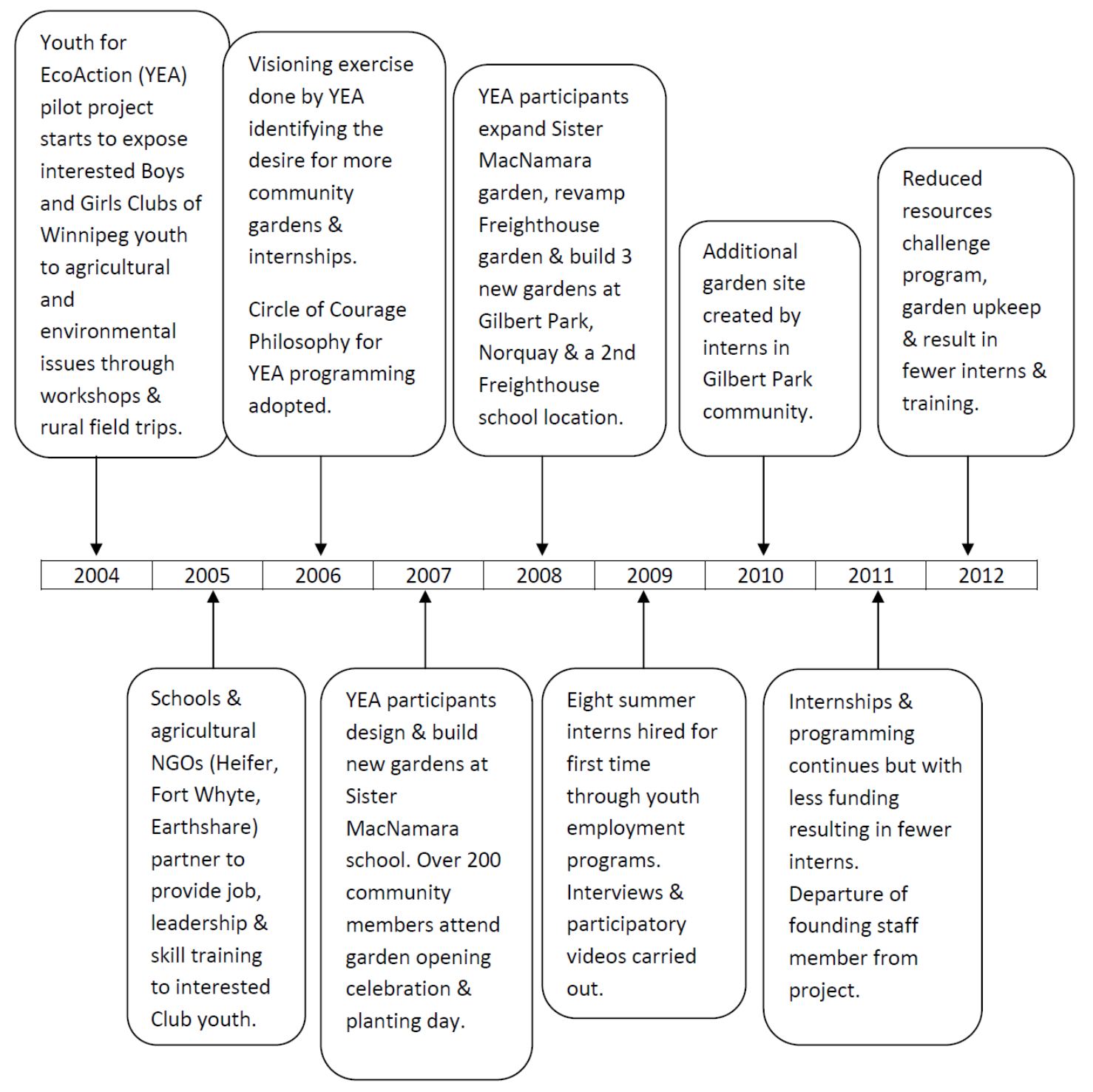

\section{THE YOUTH FOR ECOACTION PROGRAM OF THE BOYS AND GIRLS CLUBS OF WINNIPEG}

Although a lack of green space is a common concern for many North American inner-city neighbourhoods, including in Winnipeg, this deficit is being addressed in the city through the innovative YEA program. This program uses the limited green space available and converts existing public space to community gardens. The YEA Project is an enhanced program of the Boys and Girls Clubs of Winnipeg. The Boys and Girls Clubs of Winnipeg are a community-based, youth-serving agency with over 35 years of operation. The mission of the organization is to provide safe, supportive places where children and youth can experience new opportunities, overcome barriers, build positive relationships, and develop confidence and skills for life (BGCW, 2010). 


\section{Fulford \& Thompson (2013)}

The YEA program developed from an after-school program focused on gardening to an internship program for youth. The timeline is shown in Figure 1. The YEA program began in the summer of 2004 as a small pilot project involving youth members aged 9 to 18 in after-school environmental programming with a focus on urban agriculture and gardening projects. In 2005, YEA established partnerships with inner-city schools and Winnipeg-based environmental and urban agriculture projects and organizations. By partnering with Earthshare Farm, Marymound School, R.B. Russell School, Gordon Bell High School, FortWhyte Alive, and Heifer International, the organization was able to expand the YEA program to include more skill-building and training opportunities and to be more community based. In 2006, a visioning exercise took place with YEA staff and participants. This event identified their desire to build community gardens, establish internships to provide job opportunities for youth, and adopt the Circle of Courage model philosophy in their programming. The next year, one garden was built at the Sister MacNamara Club, resulting in huge fanfare, with 200 people attending the opening celebration. The following year, major garden expansion and creation took place - so that gardens were very visible in four communities - together amounting to over 50 garden beds. There were 192 participants in the four YEA Clubs in 2009, and their ages ranged from 9 to 18 years of age. Only in 2009 did youth internships start with summer hires from Boys and Girls Clubs of Winnipeg participants. These internships continue to the present day, but the internships have been reduced in number due to a decline in funding for youth employment and youth projects through provincial funding programs.

Through YEA, participants and interns visit farms, gain experience in seed starting, transplanting, and gardening, participate in food preparation and preservation workshops, and engage in other environmental learning activities. One of the major components of the YEA program is the building and maintenance of community gardens in YEA neighbourhoods, combined with a summer internship program for older participants. Club staff and the YEA coordinator recommend members for this summer employment based on interest and commitment to the program, while considering gender equity and cultural diversity.

\section{The Youth for EcoAction neighbourhoods}

The majority of the YEA programming is based out of four Boys and Girls Clubs of Winnipeg, all of which are in marginalized low-income neighbourhoods (Statistics Canada, 2006). Like all of the areas that the Clubs operate out of, these four communities struggle with high levels of poverty, substance abuse, crime, and gang activity (CCPA-MB, 2012; Carter, 2009; Skinner \& Masuda, 2013). These neighbourhoods often lack necessary services, such as grocery stores, and include many new immigrants and Aboriginal residents without social networks in the city (Carter, 2009). Aboriginal and immigrant communities in inner-city Winnipeg have lower success rates in formal education systems, experience greater food-related health concerns, including type 2 diabetes, and face increased social barriers due to systemic racism and discrimination (Carter, 2009; Skinner and Masuda, 2013). As such, youth from these communities are at greater risk than Winnipeg youth as a whole.

All four communities have lower home-ownership rates and higher population densities than the city of Winnipeg average (Statistics Canada, 2006). With high rental rates and high population density, residents are unlikely to have access to a private outdoor space, such as a backyard, and do not necessarily have access to a garden or the permission or incentive to build one (CCPA-MB. 2012).

The median household incomes of the four communities range from $\$ 15,206$ to $\$ 35,807$ (Statistics Canada, 2006). These statistics are all markedly lower than the median household income in Winnipeg of $\$ 49,790$ (Statistics Canada, 2006). With low median incomes, the incidence of households living below low-income 


\section{Fulford \& Thompson (2013)}

cut off levels in all four communities is significantly higher than Winnipeg's citywide rate of $20.2 \%$. Approximately half of the households in the Burrows-Keewatin (Gilbert Park) and North Point Douglas (Norquay) communities fall below low-income cut-off levels, while over two-thirds of the households in the Centennial (Freighthouse) and Central Park (Sister MacNamara) communities are characterized as low income (Statistics Canada, 2006).

In Canada, food security is closely tied to household income. Approximately $9.2 \%$ of Canadians live in households that are food insecure. That number jumps to $35.8 \%$ for households in the two lowest income categories (Health Canada, 2007). Simply put, in a food system that is tied to purchasing power, those with the lowest incomes are most likely to be food insecure. At a community level, this has special significance for neighbourhoods with a high percentage of low-income households. For example, in the Central Park neighbourhood, $68 \%$ of households are under the Statistics Canada low-income cut off level (Statistics Canada, 2006). The low-income cut off roughly corresponds to the two lowest income categories in Health Canada's 2004 study. Based on these values, approximately one in four households in the Central Park community are expected to be food insecure.

\section{Youth for EcoAction program pedagogy}

The Circle of Courage youth empowerment pedagogy was incorporated into the YEA program in 2006. This model grew from an anthropological comparison of Western and Native American child rearing, with ties to positive psychology theory (Brendtro, Brokenleg \& Van Bockern, 1991, 2005). The incorporation of this aspect means embedding the design and delivery of this program in decolonization and anti-oppressive frameworks. Our analysis takes shape through this lens to determine the deeper outcomes, as well as offering more mainstream results. Mainstream measures provide quick and tangible results, but are criticized as embracing only Eurocentric, middle-class values. By applying the Circle of Courage framework, it is possible to see whether youth participation contributes to decolonization and anti-oppression. This approach and its analysis are in line with other decolonization approaches taken in Winnipeg's inner city. MacKinnon and Stephens (2010) discuss how non-government organizations involved in inner-city development in Winnipeg have applied a decolonization framework, stating that:

As the damage caused by colonization and oppression can have profound effects on selfesteem, sense of self-worth, self-confidence and hope at the individual level, it can also lead to a collective weakening of social capital. Reversing the damage is slow but essential to self-empowerment, emancipation and community transformation (2010, p. 286).

Decolonization is an act of resistance that is not limited to rejecting and transforming dominant ideas, but also includes recovering and renewing traditional cultural ways of learning (Mackinnon \& Stephens, 2010). Decolonization requires learning to recognize disruptions and injury and to address their causes (MacKinnon \& Stephens, 2010). To be healthy in the world requires relearning ways that are socially just, which is in line with the Circle of Courage approach (Brendtro et a.I, 1991, 2005).

The basic premise of the Circle of Courage philosophy is that all children have four basic needs for positive development. These needs are described as: 1) belonging, 2) mastery, 3) independence, and 4) generosity (Brendtro et al., 1991, 2005). The Circle of Courage authors postulate that these four basic needs in youth development are often unmet in modern Western society, resulting in broken circles and placing youth at risk (Brendtro et al., 1991, 2005; Brendtro \& Mitchell, 2010). These problems are manifested in youth behaviour that is harmful to themselves and society, as shown in the absent or distorted manifestation of normal behaviours 
(Whittington \& Nixon Mack, 2010; Brendtro \& Mitchell, 2010). Table 2 presents associated behaviours for each need on a continuum from absent to normal and then to distorted or unbalanced.

While many conventional approaches to working with at-risk youth focus on eliminating negative behaviours, the Circle of Courage model focuses on strategies that enhance positive development (Whittington and Nixon Mack, 2010; Brendtro and Mitchell, 2010). YEA staff used the Circle of Courage model to design a program that uses a variety of strategies to create positive change in youth.

Table 2: Circle of Courage Values and Behaviours along a continuum*

\begin{tabular}{|c|c|c|c|}
\hline \multirow{2}{*}{$\begin{array}{l}\text { Circle of Courage } \\
\text { Values }\end{array}$} & \multicolumn{3}{|c|}{ Manifested Behaviours } \\
\hline & Absent & Normal & Distorted \\
\hline Belonging & $\begin{array}{l}\text { Unattached } \\
\text { Guarded } \\
\text { Rejected } \\
\text { Lonely } \\
\text { Aloof } \\
\text { Isolated } \\
\text { Distrustful }\end{array}$ & $\begin{array}{l}\text { Attached } \\
\text { Loving } \\
\text { Friendly } \\
\text { Intimate } \\
\text { Gregarious } \\
\text { Cooperative } \\
\text { Trusting }\end{array}$ & $\begin{array}{l}\text { Gang Loyalty } \\
\text { Craves Attention } \\
\text { Craves Acceptance } \\
\text { Promiscuous } \\
\text { Clinging } \\
\text { Cult Vulnerable } \\
\text { Overly Dependent }\end{array}$ \\
\hline Mastery & $\begin{array}{l}\text { Non Achiever } \\
\text { Failure Oriented } \\
\text { Avoids Risks } \\
\text { Fears Challenges } \\
\text { Unmotivated } \\
\text { Gives Up Easily } \\
\text { Inadequate }\end{array}$ & $\begin{array}{l}\text { Achiever } \\
\text { Successful } \\
\text { Creative } \\
\text { Problem-Solver } \\
\text { Motivated } \\
\text { Persistent } \\
\text { Competent }\end{array}$ & $\begin{array}{l}\text { Overachiever } \\
\text { Arrogant } \\
\text { Risk Seeker } \\
\text { Cheater } \\
\text { Workaholic } \\
\text { Persevering } \\
\text { Delinquent Skill }\end{array}$ \\
\hline Independence & $\begin{array}{l}\text { Submissive } \\
\text { Lacks Confidence } \\
\text { Inferiority } \\
\text { Irresponsible } \\
\text { Helplessness } \\
\text { Undisciplined } \\
\text { Easily Led }\end{array}$ & $\begin{array}{l}\text { Autonomous } \\
\text { Confident } \\
\text { Assertive } \\
\text { Responsible } \\
\text { Inner Control } \\
\text { Self-Discipline } \\
\text { Leadership }\end{array}$ & $\begin{array}{l}\text { Dictatorial } \\
\text { Reckless/Macho } \\
\text { Bullies Others } \\
\text { Sexual Prowess } \\
\text { Manipulative } \\
\text { Rebellious } \\
\text { Defies Authority }\end{array}$ \\
\hline Generosity & $\begin{array}{l}\text { Selfish } \\
\text { Affectionless } \\
\text { Narcissistic } \\
\text { Disloyal } \\
\text { Hardened } \\
\text { Antisocial } \\
\text { Exploitative }\end{array}$ & $\begin{array}{l}\text { Altruistic } \\
\text { Caring } \\
\text { Sharing } \\
\text { Loyal } \\
\text { Empathic } \\
\text { Pro-Social } \\
\text { Supportive }\end{array}$ & $\begin{array}{l}\text { Noblesse Oblige } \\
\text { Over Involved } \\
\text { Plays Martyr } \\
\text { Co-Dependency } \\
\text { Overinvolvement } \\
\text { Servitude } \\
\text { Bondage }\end{array}$ \\
\hline
\end{tabular}

${ }^{*}$ Modified from Brendtro, Brokenleg, \& Van Bockern, 1991

Belonging describes the need of youth to feel respected and connected to something larger than themselves (Brendtro et al., 1991, 2005). Youth desire to feel comfortable with and appreciated by the people in their lives. Youth who have a sense of belonging tend to demonstrate more caring, friendly, and cooperative 


\section{Fulford \& Thompson (2013)}

behaviour than their peers. A sense of belonging can also extend to nature, and an appreciation for the interconnectedness of our environment.

Mastery represents the requirement of youth to feel a sense of accomplishment or achievement. In the Circle of Courage model, mastery emphasizes reaching personal goals and personal bests, and is not competitive in nature or limited to success in school (Brendtro et al., 1991, 2005). With a sense of mastery, youth gain self-confidence and self-direction; they are more likely to pursue new learning opportunities and more willing to risk failure. In the absence of mastery, youth may be unmotivated and avoid risks. If mastery is distorted, youth may cheat, be arrogant, or practice a delinquent skill.

Independence requires youth to have control over themselves and their lives (Brendtro et al., 1991, 2005). For youth to have independence, they must take responsibility for personal choices and actions. This search for independence involves youth in advocating for themselves, setting their own goals, and making decisions and problem solving around personal issues. Youth who have a feeling of independence are generally more confident, more self-disciplined, and show greater leadership. Independence is fostered through leadership training and encouraging responsibility. In the absence of independence, youth may have feelings of inferiority and helplessness and be easily led into gangs, which have a strong presence in these low-income communities (Carter, 2009). If distorted, youth may bully, be manipulative, or defy authority.

Generosity is a way for youth to feel that they are making positive contributions to the lives of others (Brendtro et al., 1991, 2005). Youth gain feelings of self-worth and self-esteem through demonstrating generosity. Youth who experience generosity are more likely to have healthy relationships, stronger support networks, and a greater sense of purpose. In the absence of generosity, youth can become selfish, antisocial, and narcissistic. If generosity becomes distorted they may become over involved, a martyr, or co-dependent.

Together, the four values of belonging, mastery, independence, and generosity create a framework for positive development and decolonization in youth. These values form the underlying model for all YEA programming to lead to more positive outcomes for the individual and the broader community.

\section{METHODOLOGY}

Data was gathered using participant observation between 2008 and 2010 and semi-structured interviews and participatory video research in the summer of 2009. Interviews were conducted with seven youth interns and three Boys and Girls Clubs of Winnipeg staff. All interns were recruited for interviews, with seven of the eight interns participating. Three of the five Boys and Girls Clubs of Winnipeg staff were interviewed; one was the YEA program coordinator and the remaining two were club managers with involvement and awareness of the YEA program over a number of years. The lead author had volunteered with participants since the inception of the YEA program, assisting with the weekend field trips and participating in community garden design and construction. This provided years of observation. The lead author witnessed the development of the participants over the years, as all of them had been participants for at least one or more years prior to their internships. The interviews were used to verify Boys and Girls Clubs of Winnipeg reports and observations over the preceding five years.

Interview themes were explored for the impact of the YEA program. Benefits of YEA were categorized into two frames of reference: 1) benefits to the YEA interns and 2) benefits to the community as a whole. These benefits were further broken down and assigned either a strong positive rating if unanimously reported among all participants and staff, or a weak positive rating if multiple accounts were given, but without

ANSERJ To be notified about new ANSERJ articles, click subscribe / s'inscrire ici. 
consensus. These outcomes were further analyzed as to whether they demonstrated the values outlined in the Circle of Courage model.

\section{RESULTS AND DISCUSSION}

The YEA program had a wide variety of positive benefits at both the individual and community levels. This is consistent with benefits seen from other community youth recreation programs, which have been shown to have impacts at multiple levels: individual, family, and community (Briand et al., 2011; Lautenschlager \& Smith, 2007; Trinidad, 2009). The impacts were most profound at the intern level, as shown in Table 3. The benefits of the program are categorized into five areas: skill building and job training; self-esteem; nutrition and food security; environmental awareness and behaviour; and community building.

Table 3: Benefits of the YEA program to participants and community

\begin{tabular}{|l|c|c|}
\hline Reported Benefits of the YEA Program & Effect on Youth Participants & Effect on Community \\
\hline Skill Building and Job Training & $\sqrt{ }$ \\
\hline Gardening skills & $\sqrt{ }$ & + \\
\hline Job training & $\sqrt{ }$ & + \\
\hline Communication skills & $\sqrt{ }$ \\
\hline Leadership development & & + \\
\hline Self-Esteem & $\sqrt{ }$ \\
\hline Individual sense of pride/accomplishment & $\sqrt{ }$ \\
\hline Increased community pride & $+\sqrt{ }$ \\
\hline Nutrition and Food Security & $+\sqrt{ }$ \\
\hline Healthier eating & $+\sqrt{ }$ & + \\
\hline Food system knowledge & + & + \\
\hline Food security & + & + \\
\hline Environmental Awareness and Behaviour & & + \\
\hline Environmental awareness & & + \\
\hline Environmental behaviour & & \\
\hline Community Building & & + \\
\hline Community building & & \\
\hline
\end{tabular}

$\sqrt{ }=$ reported unanimously; $+=$ multiple positive responses; n/a = not applicable 


\section{Fulford \& Thompson (2013)}

\section{Skill building and job training}

The YEA program was designed to provide education and hands-on skill building, which addressed the need for youth to experience mastery (BGCW, 2010). The YEA programming was reported by all staff and interns interviewed to have successfully fostered a wide variety of gardening and landscaping skills. Participants engaged in vegetable production, vermicomposting, aquaponics, and beekeeping operations through FortWhyte; built raised bed gardens and a greenhouse at Earthshare headquarters; volunteered as camp leaders with FortWhyte's Agriculture Adventures Camp; participated in market vegetable sales; and attended conferences and training opportunities. Interns reported gaining experience and a sense of mastery in seed starting, weeding, watering, and more complex gardening concepts such as companion planting and traditional medicines. All participants also mentioned building compost bins and raised garden beds as a new experience.

The possibility of future employment due to increased horticultural knowledge is considered to be a benefit of youth community gardening programs (Cammack, Waliczek, \& Zajicek, 2002). Thus, horticultural knowledge increases their employability and independence. General job skills were gained through the YEA program. Youth learned general competences and behaviours essential for obtaining successful work experiences and reaching positive goals in the future. Staff members highlighted how the youth developed a strong work ethic and transferable job skills:

They're out there, and they're sweating and they're there every day and doing it without constant supervision, which is amazing at their age. The work skills are so important, because that's going to equip them to get jobs in the future, which is a huge thing for our youth. (Interview, Club Manager)

Participants also mentioned job experience as a benefit of the program. One intern, when asked if the program had made any change in his life, responded: "Yes. It's good job experience. Actually, I didn't want this job. My mom forced me, and that changed my life ... I'm really glad that my mom forced me!" These responses demonstrate the importance of building job skills and gaining employment experience for gaining mastery and independence.

Benefits to the community were received in three ways: 1) work experience that developed skills; 2) skill transfer from the interns to other community members; and 3) the impact of the program on non-YEA club members. All interns in the program gained skills and job experience, which is a positive development for the community as a whole. Five of the seven interns interviewed indicated that they had already put these skills to use outside of the YEA program, helping out family members, teaching younger children, and in the case of one participant, growing food for his family at home. Younger children were also engaged in different ways, with both club managers reporting a shift in the attitudes of many of the club youth. A staff member described witnessing this shift over the course of the summer:

A lot of it is YEA, because that was such a visual example for the kids that, "Hey, these kids volunteered and now they've got a job, right?" So they can see them working all summer and getting rewards for their work. So now I get questions every day: "Can I volunteer at the club?" "Can I volunteer?"

This demonstrates a significant cultural shift in non-YEA members as a result of the YEA program.

ANSERJ To be notified about new ANSERJ articles, click subscribe / s'inscrire ici. 


\section{Fulford \& Thompson (2013)}

\section{Self-esteem and belonging}

This program helped participants to develop self-esteem and a sense of belonging. Belonging is incorporated into YEA activities by encouraging dialogue, engaging the youth in planning sessions, incorporating peer tutoring, having regular team-building exercises, and celebrating achievements. YEA members are also required to sign agreements to join the program and are given matching YEA T-shirts to show they are part of a program.

All participants indicated their pride in their work and in the resulting community gardens and community change. One participant shared a sense of increased belonging and pride:

I feel proud, because not only am I doing it for myself, but I'm helping out them, I'm helping out my community by building gardens so that everyone can survive and provide for each other.

This youth indicated that a strong sense of individual pride and accomplishment was gained by the work, but also a sense of belonging.

Despite the difficulty in separating the origin of positive change in a young person's life, with the multiple influences of school, friends, family members, media, and participation in sports and other community programming, people credited the YEA program. All the staff members interviewed thought that the YEA program had a positive effect on the participants' leadership development, communication skills, and selfesteem. One club manager shared his observations about a specific participant:

He was one of the most sheepish guys ... he was never one to approach someone in a higher position, you would have to approach him, but now these days you can see him walking out there, and he's approaching you and he's willing to communicate ... Knowing him for the past two years l've seen such a development in him ... He's flourished in the last year, his confidence levels are up, and he's more vocal as a person. So I really think that the program has taught him a lot of responsibility and those interpersonal skills that are needed in life, and I can definitely attribute that to the YEA program.

The increase in confidence witnessed in this participant was attributed largely to his involvement with the YEA program. This demonstrates a significant benefit at the individual level as a result of the YEA program.

\section{Nutrition and food security}

The focus of the program was gardening, nutrition, and food security. Thus, these were potential areas of impact and learning for YEA participants. Intern responses to questions around food consumption and values were mixed. All interns indicated that they knew more about how food was produced, with some sharing knowledge of organic and local production. Most but not all youth interns noted changing their diet to eat more fruits and vegetables. Most interns stated that they were eating more fruits and vegetables, and eating healthier overall since joining the YEA program. However, one intern stated: "As long as it's food, it's food to me," indicating that he didn't care about what he was eating or where it came from. This is consistent with other youth gardening programs (Robinson-O'Brien et al., 2009), which show most youth do improve her/his eating habits but that all youth do not register this change.

ANSERJ To be notified about new ANSERJ articles, click subscribe / s'inscrire ici. 


\section{Fulford \& Thompson (2013)}

All interns demonstrated an increase in food issues awareness. The youth spoke with knowledge about organic foods, growing gardens without chemicals, local food vs. food from the supermarket, and global food production. This knowledge may have had or will have an impact on their food choices. These changes may manifest more as they grow older and have their own households, as the youth gain more control over their food purchases and meals made in the home. A study by Wansink showed that the largest influence on people's diets is the "nutritional gatekeeper" of the household, the person who is most responsible for purchasing groceries or otherwise obtaining food (Wansink, 2006). This is a role that many of the interns may transition into, but are not currently filling at their age.

Community-level nutrition changes were most evident with neighbourhood children and with the youngest members of the clubs. Staff indicated a greater willingness among the children to eat vegetables during snack times as a result of trying things from the garden:

A lot of kids have turned into vegetable eaters now, which is great. They have expectations that we're going to have carrots or we're going to have beans every once in awhile. It wasn't always a regular thing, but now even if it doesn't come from the garden they know that we need these vegetables and we need to be eating these things.

A willingness to try new foods and to eat healthy snacks is a significant nutritional change for club members. Staff also indicated that neighbourhood youth were learning about how food was grown as a result of the community gardens:

They know that it can be grown right in your own backyard, or your front yard, or in the community garden itself, and they just love to see that development of a YEA member bringing it in, and they'll say "where did you get that from?" and they say "it's from the garden" and they'll say "Really?" "Yeah, we just pulled it out." And it's great. They know that food is not just from Safeway [supermarket chain].

Increasing the knowledge of how food is grown, and generating excitement around gardening can result in a long-term benefit for the children in the community. The presence of community gardens in the neighbourhood also means that more food is being produced locally, improving community food security. The community garden provides a relatively small proportion of the food needs of the community at the moment, but builds infrastructure, skill development, and independence that will also have longer-term impacts.

\section{Environmental awareness and behaviour}

All interns reported a higher level of environmental awareness. The youth all raised the following topics in interviews: composting, recycling, littering, and the use of chemicals in food production. When asked if the YEA program had changed how they thought about the environment, one intern responded: "Lately I haven't been throwing my trash on the ground like I always used to, now l'm thinking more about the environment." This response indicates that there are cases where the participant's attitudes and behaviour are both changing as a result of the program.

Some youth deeply embraced environmental principles. One youth interviewee revealed the importance of safeguarding the environment to grow abundant and healthy food. Staff reported that this same intern took the initiative to instruct younger kids about what waste could be composted when he saw them throwing 


\section{Fulford \& Thompson (2013)}

organics in the trash. While not all participants demonstrated this level of environmental commitment, all participants did indicate that the environment was important to them.

Staff reported changes in community environmental behaviour as a result of the YEA program due to the public presence of the community gardens and the composting bins. Caring for the community gardens, cleaning up litter in the community, and fostering respect for the environment not only cultivated environmental stewardship, generosity was also exhibited by youth participants. Youth participants remarked that community members were taking care of the area better, stating that: "The community is a lot cleaner after we started cleaning it-people have been cleaning up after themselves." This observation indicates a change in community attitudes toward green spaces and the community as a whole.

\section{Community building}

The YEA program operates in low-income neighbourhoods dealing with high levels of poverty, substance abuse, crime, and gang activity with goals of building community and community gardens. Community gardens provide a place of gathering in neighbourhoods with few green spaces or parks.

In 2007, YEA designed and built its first community garden, located at the Sister MacNamara Club site. Participants were involved in all stages of the planning, design, and creation of the garden, including prepping the site, building beds, and hauling soil. The opening of the garden was a ceremony attended by over two hundred community members. The event included a garden tour, planting, and a celebration. YEA participants assisted younger children at the event in planting tomatoes, peppers, squash, and broccoli. This event initiated the main community-based component of the YEA program.

The community gardens provide a source of pride and accomplishment for interns. As a result of their involvement in the program and the community gardens, all youth reported a different attitude toward their communities. One intern when speaking of the gardens stated that: "People can realize that something that used to look all crummy can look so beautiful and that they can admire it. It's nice to have something gorgeous in our community." This quote captures how the intern felt the program was transforming the community, and its wider impact on community members. Another intern shared that his own perspective on his community had significantly changed: "I used to think that Gilbert Park wasn't a nice place before, until YEA came, and Gilbert Park got nicer, and the environment got prettier." These responses indicate a strong positive change in interns' attitudes toward their community.

The most noticeable change was a more positive attitude toward youth due to the work of the YEA interns and an upsurge in community garden appreciation. All youth and staff members reported positive interactions with community members. One participant stated: "Some people come by and stop and say, 'Wow, you guys are doing a great job, keep it up,' and make nice comments." A club staff member echoed this comment:

We've heard all kinds of comments from other neighbouring organizations as well as community members saying that they're just shocked that a few short years ago it was a decrepit place that was unsafe and there was junk in there, and how it's just turned into this beautiful landscape and they're just totally in awe and impressed with what it's done for the community ... there's been a really positive community response. Everybody seems to take ownership of it.

This positive response included a new interest from teachers in utilizing the garden spaces for classroom lessons on plants and vegetables. The gardens also attracted interest from community members and 
agencies requesting space at the sites. The gardens were highly visible evidence of the Boys and Girls Clubs of Winnipeg presence, bringing positive attention and publicity to the agency as a whole. Increased support for an important community youth-serving agency can only result in a benefit to the community as a whole.

\section{YEA PROGRAMMING AND THE CIRCLE OF COURAGE}

The values of the Circle of Courage program were incorporated into the YEA program. After analyzing the data and documenting the benefits of the program to participants and the community, the original program goals were considered in relation to the Circle of Courage model. Table 4 lists each of the benefit areas of the program and the Circle of Courage value they express. Some benefits overlap into multiple value areas.

Table 4: YEA benefits as Circle of Courage values

\begin{tabular}{|c|c|c|c|c|}
\hline \multirow{2}{*}{$\begin{array}{l}\text { Reported benefits of the } \\
\text { YEA program }\end{array}$} & \multicolumn{4}{|c|}{ Circle of Courage Values } \\
\hline & Belonging & Mastery & Independence & Generosity \\
\hline Gardening skills & & $\sqrt{ }$ & & \\
\hline Job training & & $\sqrt{ }$ & $\sqrt{ }$ & \\
\hline Communication skills & & & $\sqrt{ }$ & \\
\hline Leadership development & & & $\sqrt{ }$ & \\
\hline $\begin{array}{l}\text { Individual sense of } \\
\text { pride/accomplishment }\end{array}$ & & $\sqrt{ }$ & & \\
\hline Increased community pride & $\sqrt{ }$ & & & $\sqrt{ }$ \\
\hline Healthier eating & & & $\sqrt{ }$ & \\
\hline Food system knowledge & $\sqrt{ }$ & $\sqrt{ }$ & & \\
\hline Food security & & & $\sqrt{ }$ & \\
\hline Environmental awareness & $\sqrt{ }$ & $\sqrt{ }$ & & \\
\hline Environmental behaviour & $\sqrt{ }$ & & $\sqrt{ }$ & $\sqrt{ }$ \\
\hline Community building & $\sqrt{ }$ & & $\sqrt{ }$ & $\sqrt{ }$ \\
\hline
\end{tabular}

The YEA appears to be successful at nurturing all four value areas through different aspects of its programming. Some areas were easier to identify than others. For example, it was most evident that youth demonstrated mastery at gardening skills through the beauty and productivity of their garden, and they were able to share their knowledge with others. Participants gained pride and self-esteem from the many community members who showed their appreciation of the community gardens, as well as a sense of belonging in the community. Aspects of environmental stewardship and community building were not only considered to engage generosity values but also values of belonging and independence. These values are in line with discussion around traditional Aboriginal perspectives of belonging in the Circle of Courage literature:

The sense of belonging extended to nature as well. Animals, plants, people, and streams all were interdependent. From childhood, children were taught through stories that if this harmony was upset, tragedies could result. All are related, and one's actions impinge on the natural environment. Maintaining balance[d] ecological relationships is a way of ensuring balance in one's own life. (Brendtro, Brokenleg, \& Van Bockern, 1990, p. 41) 


\section{Fulford \& Thompson (2013)}

This perspective was echoed by one of the participants during an interview session whose comment on how the environment feeds us demonstrated an interconnected perspective toward the environment. One participant kept being asked by different youth where the food they were distributing came from and replied, "The food is from the garden ... And it's great, they know that food is not just from Safeway, but that it is the earth that feeds us."

Certainly all four values are overlapping in the YEA program, and together they work toward positive development for youth participants. This approach is decolonizing for youth and building social capital in the community. When looking at the program from a community and societal level, it is interesting to compare the financial costs of the program in the context of working with at-risk youth and crime prevention. With roughly $\$ 100,000$ in funding per year, organizations like the Boys and Girls Clubs of Winnipeg could run a YEA program, reaching dozens of at-risk youth, with multiple benefits extending into the community. Comparatively, $\$ 100,000$ is the amount it costs on average to incarcerate a youth for one year (John Howard Society of Manitoba, 2011).

\section{CONCLUSION}

For lower-income neighbourhoods experiencing social, economic, and physical barriers, youth community gardening programming can be an effective strategy for community development and youth empowerment. Applying decolonizing pedagogy through the Circle of Courage model, the YEA program created many positive changes in the lives of participants. Youth experienced benefits in the areas of skill building and job training; self-esteem; improved nutrition and food security; environmental awareness and behaviour; and community building. The program provided many opportunities for youth to develop the four Circle of Courage values of generosity, independence, mastery, and belonging. Benefits were also felt at a broader community level, through the human development of the interns and other youth in the neighbourhood, but also the natural, social, and physical improvements brought about by the community gardens.

Working on a relatively small budget, the Boys and Girls Clubs of Winnipeg have achieved significant impacts in the lives of youth and the community as a whole through the YEA. The program has trained and employed youth, improved community green spaces, created gardening infrastructure, and improved community food security. These are remarkable achievements and are worth replicating in other communities where willing schools and youth organizations exist. This finding is similar to other studies where at-risk youth have been employed in youth community development programs focused on gardening.

For organizations looking to the YEA program as a model to replicate, four best practices of the YEA program should be considered:

1) The Circle of Courage model is the basis of the YEA program and influenced all aspects of programming. The Circle of Courage model should be considered in the planning stages of a youth gardening program to ensure that the program incorporates decolonization and youth empowerment. The model would also be applicable for non-gardening youth programming.

2) The graduated stages of the programming, with different activities and involvement for different age groups, are a strength of the YEA program. By having different levels of programming, there is room for growth for individual participants and goals for them to work toward. This strategy also allows for the older participants to teach and act as mentors and role models for the younger members. 


\section{Fulford \& Thompson (2013)}

3) The YEA program is based around community gardens and activities within the home communities of the involved participants. The program features field trips and workshops outside of the communities, but the majority of programming takes place in the inner city. This has resulted in benefits to the communities, as well as to the participants, who feel proud of their contributions to their own communities. Some examples of youth gardening programming in North America focus on bringing participants to suburban, peri-urban, and rural locations to engage in horticultural activities. That the YEA program is based in the inner city is a strength of the program, working with the at-risk youth in their neighbourhood to make change.

4) The YEA program is a collaborative effort between community organizations, environmental organizations, local schools, and community volunteers and mentors. This collaborative approach has allowed for a wealth of experience, knowledge, and skills to be contributed to the program. This approach enhances the program, and allows for a variety of participants and staff members to be involved, as not everyone is required to be an expert in all areas.

The major barriers to successfully running a similar youth gardening program are staffing and funding. The YEA program was lucky to have a "champion," who went to great efforts to develop the program and bring together interested individuals and organizations. Having an individual, or a group of individuals who are passionate, dedicated, and skilled in program development is key to getting a similar program running successfully.

Adequate multiyear funding is necessary for a program to build on successes from year to year and for stability in the program. Although input costs for the program are relatively low, funding is required to cover a coordinator's salary, and for summer intern wages. These costs can be matched by in-kind contributions and volunteer labour, but for a successful program, cash funding sources are required. Obtaining sufficient, sustainable funding can be a major barrier to the implementation of the YEA model of youth gardening programming.

With $\$ 100,000$ in funding, organizations like the Boys and Girls Clubs of Winnipeg are able to run programming that reaches dozens of at-risk youth with benefits that extend to the community. In contrast, this is the cost to incarcerate a single youth for one year (John Howard Society of Manitoba, 2011). When programs incorporate Circle of Courage values, youth needs are met in ways that make them immune to crime. This pedagogy, with the community gardening and skills training, provides many positive aspects in the participants' lives and ripples outward into the broader community. These findings confirm the results of similar studies (Gatto et al., 2012; Ober Allen et al., 2008; Rahm, 2002, Lautenschlager \& Smith 2007; Trinidad, 2009). Community youth gardening projects provide many benefits by offering employment and training for at-risk youth, reconnecting urban youth to nature, and allowing youth to participate in community development to their individual and broader societal benefit.

\section{ACKNOWLEDGEMENTS}

The authors would like to thank the staff and participants of the Boys and Girls Clubs of Winnipeg for their contribution to this research, and Dr. Peter Elson for his helpful suggestions and careful editing of this article. 


\section{REFERENCES / BIBLIOGRAPHIE}

Boys and Girls Clubs of Winnipeg. (2010). Annual report. Winnipeg, MB: Boys and Girls Clubs of Winnipeg.

Brendtro, Larry K., Brokenleg, Martin, \& Van Bockern, Steve. (1990). Reclaiming youth at risk: Our hope for the future. Bloomington, IN: National Educational Service.

Brendtro, Larry, Brokenleg, Martin, \& Van Bockern, Steve. (1991). The circle of courage. Beyond Behavior, 2, $5-12$.

Brendtro, Larry, Brokenleg, Martin, \& Van Bockern, Steve. (2005). The circle of courage and positive psychology. Reclaiming Children and Youth, 14, 130-136.

Brendtro, Larry K. \& Mitchell, L. (2010). Weighing the evidence: From chaos to consilience. Reclaiming Children and Youth, 19(2), 3-9.

Briand, Louise, Sauvé, Nathalie, \& Fréchette, Lucie. (2011). The benefits and economic value of community recreation: Proposal for an analytical framework based on an exploratory study. Canadian Journal of Nonprofit and Social Economy Research, 2, 24-44.

Brown, Katherine, \& Carter, Anne. (2003). Urban agriculture and community food security in the United States: Farming from the city center to the urban fringe. Venice, CA: Community Food Security Coalition.

Cammack, Carol, Waliczek, Tina, \& Zajicek, Jayne. (2002). The green brigade: The educational effects of a community-based horticultural program on the horticultural knowledge and environmental attitude of juvenile offenders. Hortechnology, 12, 77-81.

Carter, Thomas. (2009). Housing and neighbourhood challenges of refugee resettlement in declining inner city neighbourhoods: A Winnipeg case study. Journal of Immigrant \& Refugee Studies, 7(3), 308-327.

CCPA-MB. 2012. State of the inner city 2012: Breaking barriers building bridges. Winnipeg, MB: CCPA. http://www.policyalternatives.ca/publications/reports/state-inner-city-2012\#sthash.06kofpOb.dpuf .

Chawla, Louise. (1998). Significant life experiences revisited. Journal of Environmental Education, 29(3), 11-21.

Douglas, David J.A. (1994). Community economic development in Canada. Toronto, ON: McGraw-Hill Ryerson.

Fieldhouse, Paul, \& Thompson, Shirley. (2012). Tackling food security issues in indigenous communities in Canada: The Manitoba experience. Nutrition and Dietetics, 69(3), 217-221.

Gatto, Nicole M., Ventura, Emily E., Cook, Lauren T., Gyllenhammer, Lauren E., \& Davis, Jaimie N. (2012). LA Sprouts: A garden-based nutrition intervention pilot program influences motivation and preferences for fruits and vegetables in Latino youth. Journal of the Academy of Nutrition and Dietetics, 112(6), 913-920.

ANSERJ To be notified about new ANSERJ articles, click subscribe / s'inscrire ici. 


\section{Fulford \& Thompson (2013)}

Health Canada. (2007). Community health survey, Cycle 2.2, Nutrition (2004)-Income-related household food security in Canada. Ottawa, ON: Health Canada.

Hoffman, August J., Knight, Luis, \& Wallach, Julie. (2007). Gardening activities, education, and self-esteem: Learning outside the classroom. Urban Education, 42, 403-411.

John Howard Society of Manitoba (2011). Winnipeg centre residents vote for getting smart on crime. [Press release]. URL: http://www.johnhoward.mb.ca .

Lautenschlager, Lauren \& Smith, Chery. (2007). Beliefs, knowledge, and values held by inner-city youth about gardening, nutrition, and cooking. Agriculture and Human Values, 24(2), 245-258.

Lawson, Lauren, \& McNally, Marcia. (1995). Putting teens at the center: maximizing public utility of urban space through youth involvement in planning and employment. Children's Environments, 12(2), 209-221.

Levkoe, Charles. (2006). Learning democracy through food justice movements. Agriculture and Human Values, 23, 89-98.

Loxley, John. (1986). The economics of community development. Ottawa, ON: Native Economic Development Program.

Mackinnon, Shauna, \& Stephens, Sara. (2010). Is participation having an impact? Measuring progress in Winnipeg's inner city through the voices of community-based program participants. Journal of Social Work, 10(3), 283-300.

Markey, Sean, Pierce, John T., Vodden, Kelly, \& Roseland, Mark. (2005). Second growth: Community economic development in rural British Columbia. Vancouver, BC: University of British Columbia Press.

Ober Allen, Julie, Alaimo, Katherine, Elam, Doris, \& Perry, Elizabeth. (2008). Growing vegetables and values: Benefits of neighborhood-based community gardens for youth development and nutrition. Journal of Hunger \& Environmental Nutrition, 3(4), 418-439.

Patel, Ishwarbhai. (1991). Gardening's socioeconomic impacts. Journal of Extension, 29(4), 7-8.

Rahm, Jrene. (2002). Emergent learning opportunities in an inner-city youth gardening program. Journal of Research in Science Teaching, 39(2), 154-184.

Robinson-O'Brien, Ramona, Story, Mary, \& Heim, Stephanie. (2009). Impact of garden-based youth nutrition intervention programs: A review. Journal of the American Dietetic Association, 109, 273-280.

Skinner, Emily \& Masuda, Jeffrey. (2013). Right to a healthy city? Examining the relationship between urban space and health inequity by Aboriginal youth artist-activists in Winnipeg. Social Science \& Medicine, 91, 210-218.

Statistics Canada. (2006). City of Winnipeg neighbourhood profiles. URL: http://winnipeg.ca/census/2006 .

ANSERJ To be notified about new ANSERJ articles, click subscribe / s'inscrire ici. 
Story, Mary, Lytle Leslie A., Birnbaum Amanda S., \& Perry Cheryl L. (2002). Peer-led, school-based nutrition education for young adolescents: Feasibility and process evaluation of the TEENS study. Journal of School Health, 72, 121-127.

Sutton, Sharon E. (2007). A social justice perspective on youth and community development: Theorizing the processes and outcomes of participation. Children, Youth and Environments, 17(2): 616-645.

Thompson Shirley, Wiebe, Jacinta, Gulrukh Kamal, Asfiah, \& Ashram, A. (2012). Analyzing food-related economic development in indigenous communities in northern Manitoba for impacts on food sovereignty, food security and sustainable livelihoods. Canadian Journal of Nonprofit and Social Economy Research 3(2).

Thompson, Shirley, Gulrukh Kamal, Asfiah, Ballard, Myrle, Beardy, Byron, Islam, Durdana, Lozeznik, Vanessa, \& Wong, Kimlee (2011). Is community economic development putting healthy food on the table?: Food sovereignty in Northern Manitoba's Aboriginal communities. Journal of Aboriginal Economic Development 7(2), 15-40.

Trinidad, Alma M. (2009). Toward kuleana (responsibility): A case study of a contextually grounded intervention for native Hawaiian youth and young adults. Aggression and violent behavior 14(6), 488-498.

Twiss, Joan, Dickinson, Joy, Duma, Shirley, Kleinman, Tanya, Paulsen, Heather, \& Rilveria, Liz. (2003). Community gardens: Lessons learned from California healthy cities and communities. American Journal of Public Health 98(9), 1435-1438.

Wakefield, Sarah, Yeudell, Fiona, Taron, Carolin, Reynolds, Jennifer, \& Skinner, Ana. (2007). Growing urban health: Community gardening in south-east Toronto. Health Promotion International, 22(2), 92-101.

Wansink, Brian. (2006). Nutritional gatekeepers and the $72 \%$ solution. Journal of the American Dietetic Association, 106, 1324-1326.

Whittington, Anja, \& Nixon Mack, Erica. (2010). Inspiring courage in girls: An evaluation of practices and outcomes. Journal of Experiential Education, 33(2), 166-180.

\section{ABOUT THE AUTHORS / LES AUTEURS}

Stephanie Fulford is an MNRM graduate of the Natural Resources Institute at the University of Manitoba. Email: stephfulford@gmail.com .

Shirley Thompson is Associate Professor in the Natural Resources Institute at the University of Manitoba. Email: s.thompson@ad.umanitoba.ca . 